\title{
Introduction
}

\section{UNHCR: The First Fifty Years}

\author{
Elisabeth RehN
}

I am very pleased to have been asked to guest edit this issue of Refuge, which is dedicated to commemorating the first fifty years of the work of the Office of the United Nations High Commissioner for Refugees. In the context of ever-increasing numbers of displaced persons, the fiftieth anniversary of the UNHCR at the end of the year 2000 presents us with an opportunity to analyze and reflect upon the achievements of this important organization as well as its weaknesses and limitations.

The articles published in this issue of Refuge present several perspectives. One pair of articles, by Brian Gorlick and Gerald Dirks, presents overviews of the history and evolution of UNHCR, stressing the shifts and expansion in the demands placed on the organization since its creation in 1951, the diversification of the responses of UNHCR to these demands, and the continuing need for the organization to be adaptable and responsive to new dimensions of the flows of the forcibly displaced.

A second group of articles provides regional examples of UNHCR's role in addressing displacement-internally and across borders. Elif Ozmenek provides an analysis of the role of UNHCR in Turkey, highlighting the relationship between the national and international refugee regimes, in a context in which Turkey is simultaneously a producer of refugees and internally displaced persons, a host of refugee populations, and a transit country. Pia Oberoi provides a historical analysis of the relationship of India and Pakistan to UNHCR, offering an explanation for the failure of both states to ratify the 1951 Convention on the Status of Refugees, and the preference of both states for ad hoc relationships with the organization. Jack Mangala examines the response of UNHCR to the "instrumentalization" of refugees and displaced persons, resulting in an increasing linkage by African states of refugees with internal and external security concerns. Finally, Edith Kauffer Michel explores the programs of UNHCR in Mexico that focus on Guatemalan refugees.

A third pair of papers bring a gendered perspective to the study of refugees and displaced persons, stressing that the needs and perspectives of refugee women deserve particular attention. These papers highlight that - while needing specific protections-refugee women must also be integrated into the decision-making that affects them. Nahla Valji studies historical and contemporary exclusion of women from the 1951 Convention, noting that the "gender-blind" parameters of the Convention have enabled states to largely ignore the realities of displaced women, and that the "gender guidelines" adopted by some states have not remedied the problem. She critiques the tendency to regard women as an indifferent, dependent mass, as "womenandchildren," separate from men, who are regarded as independent actors. Jelena Zlatkovic-Winter's review of War's Offensive on Women reminds us of the multiple contexts from which women flee, and the need for both UNHCR and state asylum policy to respond to these realities.

An additional two articles that could not be accommodated in this issue, but which also reflect on the theme of the first fifty years of UNHCR, will be included in the forthcoming issue of Refuge. In "Challenge and Change at UNHCR: A Retrospective of the Last Fifty Years," Jennifer Hyndman presents a critical reflection on the evolution of the role of UNHCR beyond its original mandate to protect refugees. In "Sex, Gender, and Refugee Protection in Canada under Bill C-11: Are Additional Protections required in light of In Matter of R-A-?" Chantal Tie highlights the analytical difficulties that arise when the persecution of women must be defined in terms of "particular social group."

Collectively, the submissions selected for this issue and the next highlight the limitations of the 1951 Convention and 
the daunting challenges faced by UNHCR today, particularly in countries in the South. The authors have noted that the 1951 Convention is not and cannot be the exclusive response to contemporary displacement, and that there are serious lacunae in both international refugee law and national asylum policies, which leave displaced persons without solutions. It is increasingly evident that the Convention-a tool developed in response to very specific historical circumstances-is poorly suited to address the needs and perspectives of developing countries, which absorb the vast majority of the world's displaced persons with a fraction of the resources available in the North. Brian Gorlick, in his article on the shifting priorities of UNHCR, quotes the Indian Permanent Representative to the un at the Fortyeighth Session of the UNHCR Executive Committee who stated, "The time has come for a fundamental reformulation of international refugee law to take into account the present-day realities ..." This is echoed by Pia Oberoi's analysis, which reveals that even countries with significant refugee flows, such as India and Pakistan, have not found the Convention to be a helpful framework, and indeed have rejected it altogether. She also quotes the Indian Permanent Representative: "The biggest donors are in reality developing countries, who put at risk their fragile environment, economy, and society to provide refuge to millions," not Northern resettlement countries. An acknowledgement of these limitations of the Convention is essential, as is a recognition of the geographic and economic realities of displacement.

Several authors also highlight the rise of racism and xenophobia in countries of the North, even in states traditionally considered to have a strong commitment to human rights. This racism is clearly reflected in the development of refugee policy of asylum states, as governments restrict admission in an effort to appease anxious electorates. The authors critique the preference of Northern governments for "humanitarian assistance" as a cheaper alternative to taking more decisive action such as military and political intervention, and as a tool to prevent displaced populations from seeking asylum in the North.

Fifty years after its creation, the UNHCR faces numerous challenges: to continue to respond to displaced populations in need, in the face of ever-present funding difficulties; to resist the politicization of protection and assistance, while balancing donor interests against the core mandate of providing meaningful assistance and protection to displaced persons throughout the world; and, against the backdrop of a convention limited in conceptualization and application, to continue to respond to the realities of displacement- as faced by women, men, and children in a multitude of contexts-ensuring that the limitations of its definition do not disentitle those genuinely in need from receiving the assistance and protection they deserve. As demonstrated by authors in this volume, the organization, despite difficulties, has shown itself to be committed, creative, and responsive in addressing the many challenges with which it has been faced. The fifty years to come will require continued commitment, creativity, and responsiveness as the challenges persist, and expand.

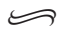

Before concluding this introduction, I would like to highlight an issue close to my heart, which is addressed by several of the authors in this volume, and which I believe merits special attention. When discussing displacement and international responses, I believe it is crucial to look at the demographics of who is actually displaced, and the impact of displacement upon them. It is often mentioned that the vast majority of the world's refugees are women and children. It is therefore essential that we consider whether the existing legal and policy framework accounts for this reality and genuinely addresses their needs. There is reason to be concerned that this is not the case.

As someone who has devoted a great deal of my career to the advancement of women, both in my own country and internationally, I must observe that while women are always among the victims of war, they are rarely present as partners in peace negotiations; despite their key stakes in the outcomes, they do not lead peacebuilding operations; they are rarely invited as local experts when new peacebuilding missions are designed; and they are almost never the spokespersons for refugees in refugee camps. The absence of women from these arenas results in a silencing of their perspectives, a lack of attention to their needs, and thus the impoverishment of refugee policy more generally. The effect of this silencing is evident not only in the policies of international organizations, but in the asylum policies of individual nations, as illustrated by the articles in this volume.

Fortunately, gender inequality has finally been brought into the daylight, after a long and arduous battle. At the end of October 2000, the Security Council unanimously accepted Resolution 1325/2000, which stresses the importance of women in all levels in peace-building, locally and internationally. Step by step, international organizations, including the United Nations, and national governments have realized that peace-building efforts cannot succed without the involvement and commitment of women. 
In the context of conflict-induced displacement, increased attention to women - to their knowledge and their needs-is essential. Women are among the first to transmit the early warnings, when alarming signals of impending conflict begin to sound. They are acutely aware of changes in everyday life, discussing developments within women's groups, and within NGos. Decision makers should therefore listen to them carefully. When situations escalate, rendering war or conflict unavoidable, women should be represented at peace negotiations. They will bring knowledge and expertise on the situation of refugees, on the possibilities for return, and on possibilities for reconciliation. Their voices must be listened to and heeded.

The recognition of women's knowledge and needs is crucial locally, nationally, and internationally. Recently, at the international level, there have been important developments. In May 2000, the "Lessons Learned" Unit of UN Department of Peacekeeping Operations arranged a conference on mainstreaming gender perspectives in peace operations, in Windhoek, Namibia. Professors, generals, politicians, women with field experience, refugee women, and several female former special representatives of the Secretary General attended the conference, convinced that the only way to achieve sustainable peace is to involve more women at all levels of peacebuilding. The result was the Windhoek Declaration-Namibia Plan of Action, which contains concrete proposals for the Secretary General, Security Council, and member governments of the UN. This declaration ultimately led to the adoption of Resolution 1325, mentioned above, which was adopted by the Security Council, on October 31, 2000.

Of course, it is clear that resolutions, reports, and plans of action are not enough, if there is no real will to achieve change. International efforts must be complemented by efforts at the national and local level. I am confident, however, that these words will eventually be turned into action, and that women will come to be regarded as people, with distinct contributions to make, rather than only as victims. The pendulum is swinging, and gender equality is finally being recognized as an international priority. In the context of displacement, and the extensive work to assist refugees and the internally displaced, this means that women's needs will be considered, as will their knowledge and potential contributions to bringing about lasting peace. Women's time has come. Naive? Perhaps, but let us share this dream.

Elisabeth Rehn has worked with numerous organizations concerned with the plight of refugees and displaced persons, including in her role as uN Under-Secretary General, Special Representative of the Secretary General in Bosnia and Herzegovina in 1998 and 1999, and as UN Special Rapporteur for the Situation of Human Rights in Bosnia and Herzegovina, the Republic of Croatia, the Federal Republic of Yugoslavia, and the Former Yugoslav Republic of Macedonia, from 1995 to 1998. She has served in the European Parliament, and was Finland's Minister of Defence from 1990 to 1995- the first female minister of defence in the world. She is presently one of two Independent Experts engaged by UNIFEM to assess the situation of women in war, particularly studying means for women to become involved in peace negotiations, and to be appointed to high-ranking peace-building posts.

\begin{abstract}
Note to Subscribers
You may have noticed an inconsistency in the numbering of the last two issues of Refuge. Volume 19.2 is dated January 2001, while 19.3 is dated December 2000. In fact, 19.2 should have been dated October 2000. This is a result of a communications lapse between two production teams during a lengthy strike at York University while both issues were being produced. Please accept our apologies for any confusion this may have caused.
\end{abstract}

